Ana Carolina Fragoso MOTTA(a) Leandro Dorigan de MACEDO(b) Gisele Guimarães SANTOS(c)

Carlos Tostes GUERREIRO(d)

Tatiane FERRARI (b)

Thais Feitosa Leitão de OLIVEIRA ${ }^{(e)}$

Paulo Sérgio da Silva SANTOS(f)

Christiano de OLIVEIRA-SANTOS(a)

Hilton Marcos Alves RICZ(h)

Samuel Porfírio XAVIER ${ }^{(\mathrm{g})}$

Odilon IANNETTA ${ }^{(h)}$

(a) Universidade de São Paulo - USP, School of Dentistry of Ribeirão Preto, Department of Stomatology, Public Oral Health and Forensic Dentistry, Ribeirão Preto, SP, Brazil.

(b)Hospital das Clínicas, Division of Dentistry and Oral Diagnosis, Ribeirão Preto, SP, Brazil.

(c) Universidade Estadual Paulista "Júlio de Mesquita Filho" - UNESP, School of Pharmaceutical Sciences, Department of Food and Nutrition, Araraquara, SP, Brazil.

(d) Universidade de São Paulo - USP, School of Medicine of Ribeirão Preto, Department of Neurosciences and Behavioral Sciences, Ribeirão Preto, SP, Brazil.

(e) Universidade de São Paulo - USP, Dental School of Bauru, Department of Stomatology, Bauru, SP, Brazil.

(f) Universidade de São Paulo - USP, School of Medicine of Ribeirão Preto, Department of Ophthalmology, Otorhinolaryngology and Head and Neck Surgery, Ribeirão Preto, SP, Brazil.

(g) Universidade de São Paulo - USP, School of Dentistry of Ribeirão Preto, Department of Oral \& Maxillofacial Surgery and Periodontology, Ribeirão Preto, SP, Brazil.

(h) Universidade de São Paulo - USP, School of Medicine of Ribeirão Preto, Department of Gynecology and Obstetrics, Ribeirão Preto, SP, Brazil.

Declaration of Interests: The authors certify that they have no commercial or associative interest that represents a conflict of interest in connection with the manuscript.

Corresponding Author:

Ana Carolina Fragoso Motta

E-mail: anacfm@usp.br

DOI: 10.1590/1807-3107BOR-2015.vol29.0106

Submitted: Apr 19, 2015

Accepted for publication: Jul 28, 2015

Last revision: Aug 24, 2015

\section{Quantitative ultrasound at the hand phalanges in patients with bisphosphonate-related osteonecrosis of the jaws}

Abstract: Patients with bisphosphonate-related osteonecrosis of the jaws (BRONJ) who received intravenous or oral bisphosphonates (BP) were selected for determination of their bone microarchitecture as a risk predictor of $\mathrm{BRONJ}$ development. The diagnosis of BRONJ was made based on clinical and radiographic findings. The control group consisted of healthy patients. All patients underwent quantitative and qualitative ultrasound measurements of bone at the hand phalanges carried out using the DBM Sonic BP. Ultrasound bone profile index (UBPI), amplitude-dependent speed of sound (AD-SoS), bone biophysics profile (BBP), and bone transmission time (BTT) were measured. The BRONJ group consisted of 17 patients (62 \pm 4.24 ; range: $45-82) ; 10$ (58.8\%) were male and seven (41.1\%) were female, of whom $11(64.7 \%)$ suffered from multiple myeloma, three (17.6\%) from osteoporosis, one $(5.8 \%)$ from prostate cancer, one $(5.8 \%)$ from kidney cancer, and one $(5.8 \%)$ from leukemia. Fourteen $(82.3 \%)$ of them received intravenous BP whereas three $(17.6 \%)$ received oral BP. Nine $(9 / 17 ; 52.9 \%)$ patients developed bone exposure: two in the maxilla and seven in the mandible. Regarding quantitative parameters, Ad-SoS was low in the BRONJ group, but not significant. The UBPI score was significantly reduced in BRONJ patients with exposed bone when compared to controls $(0.47 \pm 0.12$ vs. $0.70 \pm 0.15 ; p=0.004)$. The present study demonstrated that quantitative ultrasound was able to show bone microarchitecture alterations in BRONJ patients, and suggests that these analyses may be an important tool for early detection of bone degeneration associated with BRONJ.

Keywords: Bisphosphonate-Associated Osteonecrosis of the Jaw; Dental Care; Ultrasonography; Bone Density.

\section{Introduction}

Bisphosphonates (BP) are inhibitors of bone resorption and angiogenesis used for the treatment of diseases that affect bone metabolism, since they directly or indirectly inhibit osteoclastic bone resorption. ${ }^{1,2}$ The most important side effect of these drugs is bisphosphonate-related osteonecrosis of the jaw (BRONJ), whose definition has been recently updated as medication-related osteonecrosis of the jaw (ONJ) since it 
includes other antiresorptive or antiangiogenic agents than BPs. ${ }^{3}$ It is characterized by exposed bone of the jaw without clinical evidence of healing for at least 8 weeks in patients using BPs and without exposure to head and neck radiation therapy or metastatic disease of the jaw. ${ }^{3,4,5,6,7}$ There is a crucial need to understand the factors involving the pathogenesis of these lesions and to determine which patients may be considered at risk, since these lesions are difficult to control and lead to high morbidity.

Regarding its pathophysiology, BRONJ has been characterized by accumulation of physiological damage in the jaw bones, which results from a marked suppression of normal metabolic turnover. ${ }^{8,910}$ The presence of trauma, including dental invasive procedures and infection, increases the demand for osseous repair that exceeds the capacity of the hypodynamic bone, resulting in bone necrosis. ${ }^{9}$ In addition, the antiangiogenic effects of BP on the tissues and the presence of comorbid factors, such as immunosuppression and other pathologies, may increase the risk for progression of this condition., ${ }^{910}$

It is necessary to determine the factors that may predispose the patient to the development of osteonecrosis of the jaws. Variables such as age, gender, medications, oral microbiota, preexisting medical conditions, and individual genetic variations need to be investigated. In addition, methods for skeleton assessment may be important to determine early alterations. Quantitative ultrasound (QUS) is a method for estimating bone mineral status through measurements performed at skeletal sites with predominance of cortical bone, such as proximal phalanges. ${ }^{11}$ QUS measurements provide qualitative and quantitative features of bone related to its microarchitecture or elasticity. ${ }^{12}$ We hypothesized that QUS could detect skeletal modifications in patients with BRONJ. This study evaluated the bone microarchitecture of patients with BRONJ in order to monitor bone turnover and to determine whether these analyses could predict bone exposures.

\section{Methodology}

\section{Ethics statement}

The study was approved by the Ethics Committee of the Universidade de São Paulo - USP, School of Dentistry of Ribeirão Preto - Brazil (CAAE no. 0066.0.138.004-11). All subjects signed a written informed consent for their participation, in accordance with the Declaration of Helsinki.

\section{Patients}

Patients presenting with BRONJ (study group) selected from the Surgery Clinics of the School of Dentistry of Ribeirão Preto and from the Clinical Hospital of the Universidade de São Paulo at Ribeirão Preto participated in the cross-sectional study. The diagnosis of BRONJ was made based on the history of BP uses and clinical findings. ${ }^{7}$ Plain radiographs (panoramic radiographs) were used as adjunctive assessment in the evaluation. The clinical alterations considered were: necrotic exposure of the jaw bones without clinical evidence of healing for at least 8 weeks, oral pains and/or infection signs. The radiographic alterations considered were signs compatible with osteosclerosis, osteolysis, and thickening of the lamina dura, fragmentation of the cortex, thickening of the periosteum, sequestra, and fractures. The control group consisted of healthy patients, pooled from a database at the Teaching Hospital of the Universidade de São Paulo at Ribeirão Preto, without any condition known to interfere with bone metabolism and matched to the study group by age, gender, and race. Subjects were excluded if they had been exposed to head and neck radiation therapy.

\section{Study design}

A cross-sectional study was conducted from June 2011 to January 2012. After clinical examination, radiomorphometric indices were used to analyze alveolar bone loss: cortical width (CW), panoramic mandibular index (PMI) and degree of alveolar crest resorption (M/M ratio). $\mathrm{CW}$ is the thickness of the mandibular inferior cortex; PMI is the ratio between the thickness of the mandibular cortex and the distance between the mental foramen and the inferior mandibular cortex. The thickness of the cortex was divided by the distance from the inferior margin of the mental foramen to the inferior border of the mandible. For the $\mathrm{M} / \mathrm{M}$ ratio, the total mandibular height was divided by the height from the center of the mental foramen to the inferior border of the mandible. ${ }^{13,14}$ All measurements were made in millimeters on the same computer program (Image 
J, NIH; Bethesda, USA). When the mental foramen was visible bilaterally, the measurements were done bilaterally and the final result is an average between both; when only one foramen was visible, the measurements were done only on that side.

After clinical and radiographic examinations, all patients underwent double sequential examination of proximal phalanx metaphysis (II-IV) of the non-dominant extremity, in which soft tissue, three qualitative parameters, and one quantitative parameter were analyzed. These examinations were carried out using the DBMSonic BP (IGEA; Carpi, Italy), which consists of an electronic caliper with two ultrasound probes (emitter and receiver) recording the ultrasound modifications through the phalanx. In all double measurements, the caliper was positioned at the distal metaphysis of the proximal phalanx of the last four fingers (II to IV) of the non-dominant hand. The probes were positioned on the mediolateral phalangeal surfaces using the phalanx head as reference point. The measurements were obtained by automation and the final result of each patient showed the mean of 96 measurements. This methodology informs, by a specific window on the display, whether the technical process is correct and, if not, it automatically blocks measurement acquisition. To restart the measurements, it is necessary to reposition the caliper. This technology forces the recording of the zero reference level for soft tissues, preceding the measurements of the four distal phalanges (to increase the precision of this exam). At the end of the recording, it was possible to evaluate the coefficients of intra-rater and inter-rater reliability. The UBPI, AD-SoS, BBP, BTT, and QUS-phalanges slices were measured. ${ }^{11}$

\section{Statistical analysis}

The qualitative and quantitative parameters had normal distribution among all the patients. Comparisons between the groups were performed using the unpaired Student's $t$ test for two groups and the analysis of variance (ANOVA) for three or more. The Chi-square test on $2 \times 2$ contingency tables provided the values for the assessment of the association among categorical variables (gender, age, DBM parameters) and the presence of BRONJ. These analyses were performed using the SAS software (Statistical Analysis System - SAS ${ }^{\circledR} 9.0$ software; San Diego, USA). The data were reported as means and standard deviations (SD), and the level of significance was set at $5 \%$ in all analyses.

\section{Results}

\section{Patients}

The demographic characteristics and medical history of the subjects with BRONJ are shown in Table 1 . The study group consisted of 17 patients: $10(10 / 17 ; 58.8 \%)$ were male and seven $(7 / 17 ; 41.1 \%)$ were female. The mean age of BRONJ patients was $62 \pm 4.24$ (range: $45-82$ ), and the disease was more frequent in white subjects (13/17; $76.4 \%)$. Eleven patients $(11 / 17 ; 64.7 \%)$ were affected by multiple myeloma, three $(3 / 17 ; 17.6 \%)$ by osteoporosis, one $(1 / 17 ; 5.8 \%)$ by prostate cancer, one $(1 / 17 ; 5.8 \%)$ by kidney cancer, and one $(1 / 17 ; 5.8 \%)$ by leukemia. Fourteen $(14 / 17 ; 82.3 \%)$ of them received intravenous bisphosphonates (pamidronate or zoledronic acid) whereas the three $(3 / 17 ; 17.6 \%)$ patients with osteoporosis received oral bisphosphonates (alendronate). All patients in the study group also received previous or concomitant therapy for the underlying malignancy or associated comorbidities (Table 1).

\section{BRONJ}

Nine $(9 / 17 ; 52.9 \%)$ patients developed frank exposed osteonecrosis of the jaw (Stage 2), and it occurred in three $(3 / 9 ; 33.3 \%)$ cases without apparent precipitating events, and in six patients $(6 / 9 ; 66.6 \%)$ with history of tooth extraction (the lesion occurred at the same site of previous tooth extraction); the mandible was affected in seven cases (7/9;77.7\%) and the maxilla in two cases (2/9; $22.2 \%)$. Eight patients $(8 / 17 ; 47.05 \%)$ presented subclinical bone alterations (osteolysis and sclerosis) classified as a non-exposed variant of BRONJ (Stage 0), ${ }_{1,16}^{15}$ and these bone alterations were diagnosed by routine panoramic radiographs. Three $(3 / 8 ; 37.5 \%)$ patients presented this variant in the mandible and maxilla, four $(4 / 8 ; 50 \%)$ presented it only in the mandible, and one $(12.5 \%)$ presented it only in the maxilla. The average time from dental intervention or the beginning of the symptoms to the first examination was 8 months.

\section{Bisphosphonate therapy}

The average time of treatment with bisphosphonates until the occurrence of first symptoms of BRONJ 
- Quantitative ultrasound at the hand phalanges in patients with bisphosphonate-related osteonecrosis of the jaws

Table 1. Demographic and clinical data of BRONJ patients.

\begin{tabular}{|c|c|c|c|c|c|c|c|c|c|}
\hline Case & Gender & Age & Ethnic & $\begin{array}{l}\text { Primary } \\
\text { diagnosis }\end{array}$ & BP type & $\begin{array}{l}\text { BP use } \\
\text { (months) }\end{array}$ & Other drugs & $\begin{array}{l}\text { Precipitating } \\
\text { treatment }\end{array}$ & Affected jaw \\
\hline IAL & Female & 62 & W & $\begin{array}{l}\text { Multiple } \\
\text { myeloma }\end{array}$ & $\begin{array}{l}\text { Zoledronic } \\
\text { acid }\end{array}$ & 2 & Thalidomide, lamivudine & Dental extraction & $\begin{array}{c}\text { Mandible } \\
\text { (exposed bone) }\end{array}$ \\
\hline BRS & Female & 80 & $A D$ & Osteoporosis & Alendronate & 72 & $\begin{array}{l}\text { Carbamazepine, Clorana, } \\
\text { Atenolol, Domperidone }\end{array}$ & Dental extraction & $\begin{array}{c}\text { Mandible } \\
\text { (exposed bone) }\end{array}$ \\
\hline DUS & Female & 58 & W & Osteoporosis & Risedronate & 60 & $\begin{array}{l}\text { Simvastatin, Vitamin } \mathrm{D} \text {, } \\
\text { Calcium, Cyclobenzaprine }\end{array}$ & $\begin{array}{c}\text { Not } \\
\text { identified/spontaneous }\end{array}$ & $\begin{array}{l}\text { Mandible } \\
\text { (osteolysis) }\end{array}$ \\
\hline MGZ & Female & 82 & W & Osteoporosis & Alendronate & 48 & $\begin{array}{c}\text { Chloroquine, Atensin, } \\
\text { Calcium, }\end{array}$ & Dental extraction & $\begin{array}{c}\text { Mandible } \\
\text { (exposed bone) }\end{array}$ \\
\hline ZPB & Female & 78 & W & Leukemia & $\begin{array}{l}\text { Zoledronic } \\
\text { acid }\end{array}$ & 13 & Dasatinib & Dental extraction & $\begin{array}{c}\text { Mandible } \\
\text { (exposed bone) }\end{array}$ \\
\hline RACC & Female & 45 & W & $\begin{array}{l}\text { Multiple } \\
\text { myeloma }\end{array}$ & $\begin{array}{l}\text { Zoledronic } \\
\text { acid }\end{array}$ & 12 & $\begin{array}{c}\text { Thalidomide, Dexamethasone, } \\
\text { Acetylsalicylic acid }\end{array}$ & $\begin{array}{c}\text { Not } \\
\text { identified/spontaneous }\end{array}$ & $\begin{array}{c}\text { Mandible } \\
\text { (osteosclerosis) }\end{array}$ \\
\hline CSS & Female & 54 & W & $\begin{array}{l}\text { Multiple } \\
\text { myeloma }\end{array}$ & Pamidronate & 30 & $\begin{array}{l}\text { Metformin, Glibenclamide, } \\
\text { Hydrochlorothiazide } \\
\text { Thalidomide, Dexamethasone }\end{array}$ & $\begin{array}{c}\text { Not } \\
\text { identified/spontaneous }\end{array}$ & $\begin{array}{c}\text { Mandible } \\
\text { (osteosclerosis) }\end{array}$ \\
\hline GJS & Male & 47 & $A D$ & $\begin{array}{l}\text { Multiple } \\
\text { myeloma }\end{array}$ & $\begin{array}{l}\text { Zoledronic } \\
\text { acid }\end{array}$ & 7 & Dexamethasone, Thalidomide & $\begin{array}{c}\text { Not } \\
\text { identified/spontaneous }\end{array}$ & $\begin{array}{c}\text { Mandible } \\
\text { (exposed bone) }\end{array}$ \\
\hline ABSF & Male & 67 & W & $\begin{array}{l}\text { Multiple } \\
\text { myeloma }\end{array}$ & $\begin{array}{l}\text { Zoledronic } \\
\text { acid }\end{array}$ & 43 & Thalidomide, Dexamethasone & Prosthetic injury & $\begin{array}{c}\text { Maxilla } \\
\text { (osteosclerosis) }\end{array}$ \\
\hline EDG & Male & 50 & $A D$ & $\begin{array}{l}\text { Multiple } \\
\text { myeloma }\end{array}$ & $\begin{array}{l}\text { Zoledronic } \\
\text { acid }\end{array}$ & 51 & Thalidomide, Dexamethasone & $\begin{array}{c}\text { Not } \\
\text { identified/spontaneous }\end{array}$ & $\begin{array}{c}\text { Mandible } \\
\text { and Maxilla } \\
\text { (osteosclerosis) }\end{array}$ \\
\hline EFM & Male & 69 & W & $\begin{array}{l}\text { Multiple } \\
\text { myeloma }\end{array}$ & $\begin{array}{l}\text { Zoledronic } \\
\text { acid }\end{array}$ & 13 & $\begin{array}{c}\text { Dexamethasone, Thalidomide, } \\
\text { Bortezonib }\end{array}$ & Periodontitis & $\begin{array}{c}\text { Mandible } \\
\text { and Maxilla } \\
\text { (osteosclerosis) }\end{array}$ \\
\hline NC & Male & 54 & W & $\begin{array}{l}\text { Multiple } \\
\text { myeloma }\end{array}$ & $\begin{array}{l}\text { Zoledronic } \\
\text { acid }\end{array}$ & & Dexamethasone, Thalidomide & $\begin{array}{c}\text { Not } \\
\text { identified/spontaneous }\end{array}$ & $\begin{array}{c}\text { Mandible } \\
\text { (exposed bone) }\end{array}$ \\
\hline JSPF & Male & 59 & $A D$ & $\begin{array}{l}\text { Multiple } \\
\text { myeloma }\end{array}$ & $\begin{array}{l}\text { Zoledronic } \\
\text { acid }\end{array}$ & 63 & $\begin{array}{l}\text { Acetylsalicylic acid, Metformin } \\
\text { Thalidomide, Dexamethasone }\end{array}$ & $\begin{array}{c}\text { Not } \\
\text { identified/spontaneous }\end{array}$ & $\begin{array}{c}\text { Mandible } \\
\text { and Maxilla } \\
\text { (osteosclerosis) }\end{array}$ \\
\hline JRN & Male & 74 & W & $\begin{array}{l}\text { Prostate } \\
\text { cancer }\end{array}$ & $\begin{array}{l}\text { Zoledronic } \\
\text { acid }\end{array}$ & 25 & $\begin{array}{l}\text { Zoladex, Bicalutamide, } \\
\text { Prednisone }\end{array}$ & $\begin{array}{c}\text { Not } \\
\text { identified/spontaneous }\end{array}$ & $\begin{array}{l}\text { Maxilla (exposed } \\
\text { bone) }\end{array}$ \\
\hline AAF & Male & 68 & W & $\begin{array}{l}\text { Multiple } \\
\text { myeloma }\end{array}$ & $\begin{array}{l}\text { Zoledronic } \\
\text { acid }\end{array}$ & 14 & $\begin{array}{l}\text { Predinisone, Thalidomide, } \\
\text { Dexamethasone, Melphalan }\end{array}$ & Dental extraction & $\begin{array}{l}\text { Maxilla (exposed } \\
\text { bone) }\end{array}$ \\
\hline JMS & Male & 55 & W & $\begin{array}{l}\text { Renal cell } \\
\text { Carcinoma }\end{array}$ & $\begin{array}{l}\text { Zoledronic } \\
\text { acid }\end{array}$ & 19 & Sunitinib & Dental extraction & $\begin{array}{c}\text { Mandible } \\
\text { (exposed bone) }\end{array}$ \\
\hline ECP & Male & 56 & W & $\begin{array}{l}\text { Multiple } \\
\text { myeloma }\end{array}$ & $\begin{array}{l}\text { Zoledronic } \\
\text { acid }\end{array}$ & 9 & $\begin{array}{l}\text { Thalidomide, Mefformin, } \\
\text { Insulin, Glibenclamide }\end{array}$ & $\begin{array}{c}\text { Not } \\
\text { identified/spontaneous }\end{array}$ & $\begin{array}{l}\text { Mandible } \\
\text { (osteolysis) }\end{array}$ \\
\hline
\end{tabular}

W: white; AD: African descendant.

was 23.1 months for intravenous bisphosphonate administration (range 2-63 months) and 60 months for oral bisphosphonates (range 48-72).

\section{Bone microarchitecture analysis}

The trends of quantitative and qualitative parameters presented by BRONJ patients and control subjects are shown in Table 2. Regarding quantitative parameters, the BTT score was similar in the three groups, and the AD-SoS score was lower in the BRONJ group compared to the control (Figures 1 to 3); however, no significance was obtained. The UBPI score was significantly reduced in BRONJ patients with exposed bone when compared to controls $(0.47 \pm 0.12$ vs $0.70 \pm 0.15 ; p=0.004)$ (Table 2).

\section{Discussion}

The diagnosis of BRONJ is established based on the history of BP uses and on clinical signs and symptoms. ${ }^{7,9,16,17,18,19,20}$ Imaging exams should be used as adjunctive assessment in the evaluation of patients as they provide useful information about alterations in bone morphology that may be detectable by radiographs, computerized tomography (CT) scan, and magnetic resonance imaging (MRI). ${ }^{12,21,22}$ 
Table 2. Gender, age, and microarchitecture profile in BRONJ subjects with and without exposed bone and in controls.

\begin{tabular}{|c|c|c|c|}
\hline \multirow{3}{*}{ Variables } & \multicolumn{2}{|c|}{ BRONJ patients } & \multirow{2}{*}{ Controls } \\
\hline & With exposed bone & Without exposed bone & \\
\hline & $\mathrm{n}(\%)$ & $\mathrm{n}(\%)$ & $n(\%)$ \\
\hline \multicolumn{4}{|l|}{ Gender } \\
\hline Male & $5(55.6)$ & $5(62.5)$ & $10(58.8)$ \\
\hline Female & $4(44.4)$ & $3(37.5)$ & $7(41.2)$ \\
\hline \multicolumn{4}{|l|}{ Age (years) } \\
\hline Range & $55-82$ & $45-69$ & $45-82$ \\
\hline Mean & $68.1 \pm 10.7$ & $53.7 \pm 7.5$ & $62.2 \pm 11.5$ \\
\hline \multicolumn{4}{|l|}{ DBM parameters } \\
\hline UBPI & $0.47 \pm 0.12^{a}$ & $0.68 \pm 0.16^{b}$ & $0.70 \pm 0.16^{b}$ \\
\hline AD-SoS $(\mathrm{m} / \mathrm{s})$ & $2019.7 \pm 96.80$ & $2068.7 \pm 50.43$ & $2103.7 \pm 110.41$ \\
\hline $\mathrm{BTT}(\mu / \mathrm{s})$ & $1.52 \pm 0.32$ & $1.66 \pm 0.23$ & $1.57 \pm 0.40$ \\
\hline \multicolumn{4}{|l|}{ Microarchitecture profile } \\
\hline \multicolumn{4}{|l|}{ UBPI } \\
\hline Normal (>0.84) & $0(0.0)$ & $2(25.0)$ & $2(11.8)$ \\
\hline Limitrophe (0.70 - 0.84) & $0(0.0)^{a}$ & $1(12.5)^{a}$ & $9(52.9)^{\mathrm{b}}$ \\
\hline Inadequate $(0.44-0.69)$ & $6(66.7)^{a}$ & $5(62.5)$ & $4(23.5)^{b}$ \\
\hline Deteriorated $(<0.44)$ & $3(33.3)$ & $0(0.0)$ & $2(11.8)$ \\
\hline \multicolumn{4}{|l|}{ AD-SoS } \\
\hline Normal (> 2040) & $5(55.6)$ & $4(50.0)$ & $11(64.7)$ \\
\hline Osteopenia (2040-1949) & $2(22.2)$ & $4(50.0)$ & $4(23.5)$ \\
\hline Osteoporosis $(<1949)$ & $2(22.2)$ & $0(0.0)$ & 2 (1 1.8) \\
\hline
\end{tabular}

Different letters in the same row mean statistical difference (Chi-square test; $p<0.05)$.
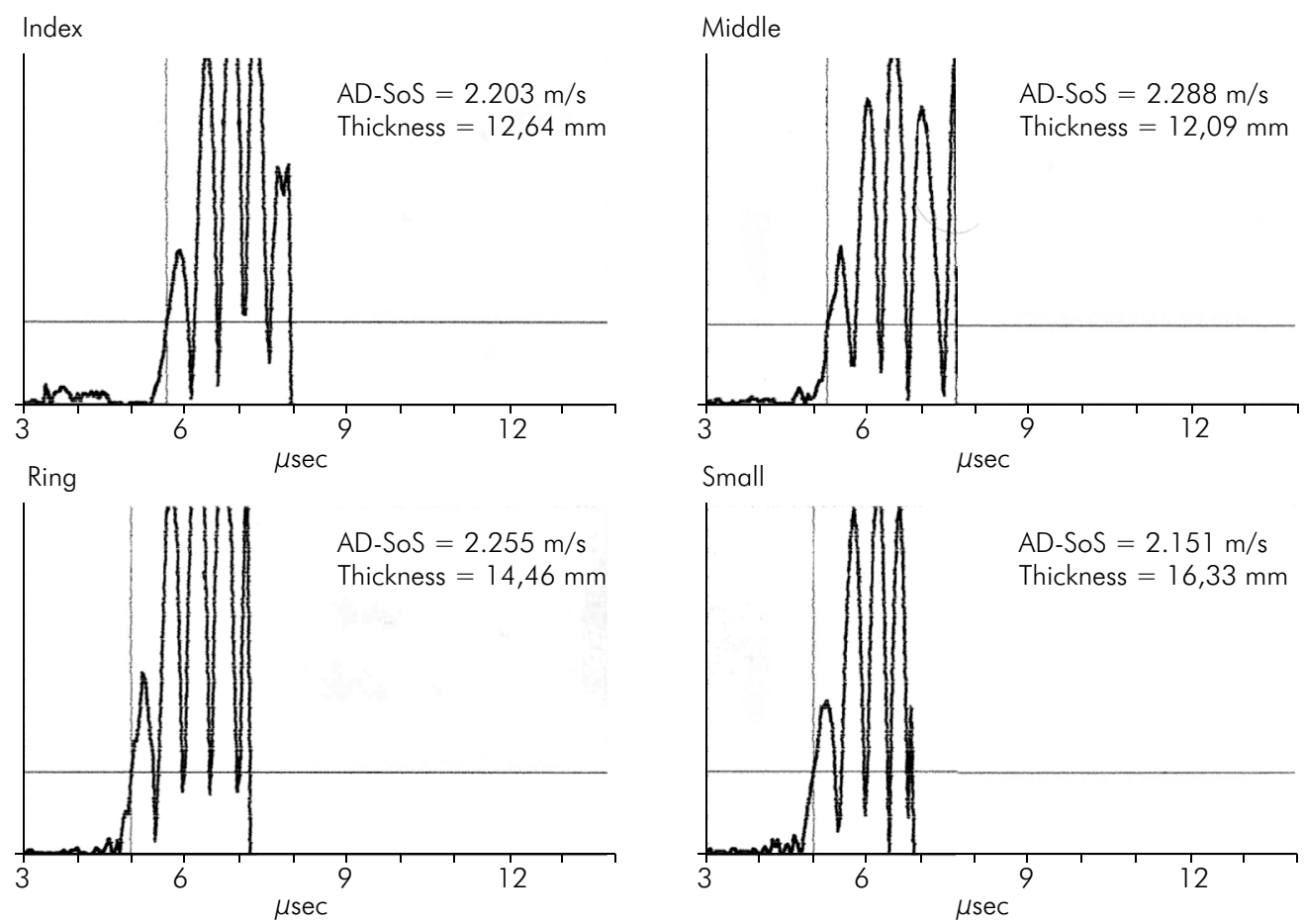

Figure 1. Biophysical bone profile of a control patient: presence of attenuation and inversion of the pulses compatible with age (74 years old). The value of AD-SoS $>2.040 \mathrm{~m} / \mathrm{s}$ classifies the patient as having normal bone quantity; patient does not present bone fracture risk. 
- Quantitative ultrasound at the hand phalanges in patients with bisphosphonate-related osteonecrosis of the jaws
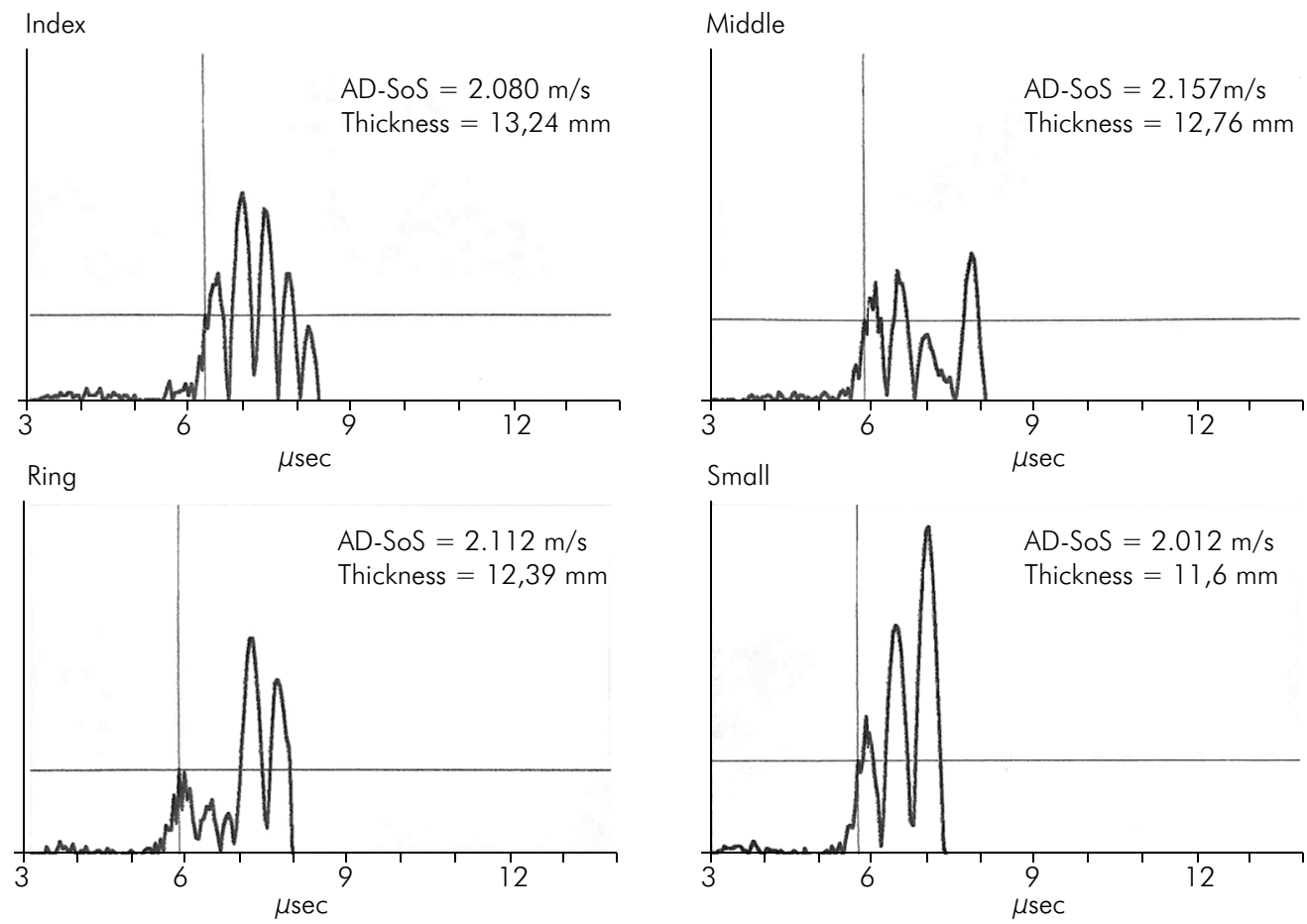

Figure 2. Biophysical bone profile of a BRONJ patient without bone exposure: most of the pulses showed attenuation and inversion. The value of AD-SoS between $1.949 \mathrm{~m} / \mathrm{s}$ and $2.040 \mathrm{~m} / \mathrm{s}$ classifies the patient as having low bone quantity; patient presents risk of osteoporotic fractures.
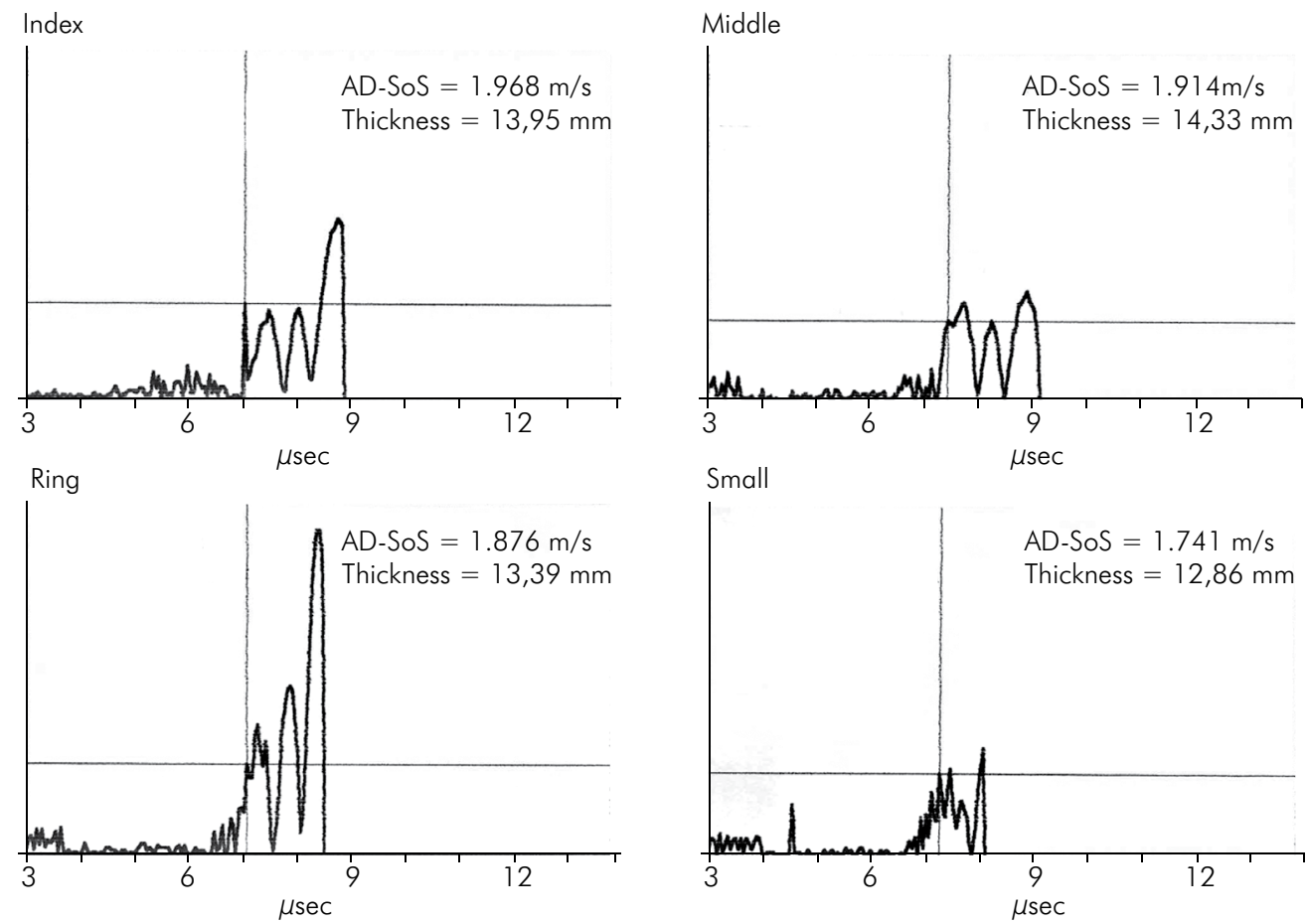

Figure 3. Biophysical bone profile of a BRONJ patient with frank bone exposure: attenuation of all pulses, high reduction of the number and inversion of the pulses. The first pulse represents long duration of total reabsorption. The value of $A D-S o S<1.949 \mathrm{~m} / \mathrm{s}$ classifies the patient as having very low bone quantity; patient presents high risk of osteoporotic fractures. 
Radiographs may be negative for early signs of BRONJ, and CT and MRI are also not useful to detect initial mineral bone loss in early cases. ${ }^{23}$ Previous studies demonstrated that CT and MRI are adequate for evaluating more significant bone involvement; ${ }^{22}$ however, in most cases, these exams show nonspecific findings, resembling those of a chronic osteomyelitic process, with predominant signs of osteosclerosis and periosteal reaction. Despite nonspecific findings, bone scintigraphy has been better at detecting early inflammatory processes than other methods. ${ }^{23,24}$ Considering that the diseased bone goes far beyond the limits of the clinically exposed bone areas ${ }^{10,12}$ and that the imaging findings may not reflect the true bone architecture, it seems reasonable to evaluate the bone microarchitecture of patients with BRONJ through the QUS method, as reported in the present cross-sectional study.

Osteonecrosis seems to be time- and dose-dependent and increased cumulative doses and long-term BP treatment are considered important risk factors for BRONJ development. ${ }^{9,24}$ However, some studies ${ }^{4,25}$ have reported that BRONJ may develop after few months of BP therapy, as demonstrated in the present study (Table 1; cases IAL and GJS). Local and systemic factors, such as oral microbiota, smoking, underlying medical conditions, previous or simultaneous therapies with glucocorticoids and/or immunosuppressive drugs might promote an additional risk for BRONJ, but the real impact of these factors remains to be determined. ${ }^{17}$ Prospective studies are needed to further elucidate BRONJ pathogenesis, and the search for methods that can determine which patients are at risk is important. Thus, bone microarchitecture analysis through QUS may be an adjuvant method for determining the risk for the development of bone necrosis.

Ultrasound measurement provides information on both bone structure and resistance to mechanical solicitations, permitting the detection of reduced bone mineral content. ${ }^{26,27}$ Phalangeal QUS evaluates bone condition through sonographic parameters strictly dependent on bone biomechanical properties. ${ }^{28,29} \mathrm{BTT}$ demonstrates cortical thickness and can discriminate different patterns of bone disease regardless of bone density; ${ }^{29}$ AD-SoS mostly reflects bone density and elasticity, being marginally influenced by structural changes in the bone; ${ }^{28}$ and UBPI provides information about the quality of bone mass. ${ }^{29}$ In the present study, BRONJ patients presenting frank bone exposure showed reduced UBPI scores compared to BRONJ patients presenting subclinical findings and control patients (Table 2). Moreover, most of the patients with subclinical BRONJ (62.5\%) presented an inadequate UBPI profile compared to the control group $(4 / 17 ; 23.5 \%)$, and this result suggests high bone mass deterioration in these patients. Radiomorphometric indices in panoramic radiographs also allow for quantitative assessment of bone mineral loss in BRONJ patients. The PMI was found to be altered in $43 \%$ of the patients when compared to the normal standards..$^{30}$

Most of the published reports regarding imaging findings of BRONJ are related to established osteonecrosis., ${ }^{47,21-23}$ There is a need to determine predictive exams that may indicate early bone pathology in the absence of clinical ONJ, and bone microarchitecture analysis may be useful for that purpose. Future additional analyses may be required to further assess the impact of QUS as a predictor of BRONJ development. In this study, QUS was not performed before BP treatment; thus, it was not possible to compare the effect of BP on bone microarchitecture. Additionally, serial analyses in BP users without BRONJ were not performed, so early skeletal changes could not be detected. The relatively small number of subjects included in this study may also be a limitation, considering the large number of BP users in the population. Furthermore, given that underlying diseases may alter bone mass, as demonstrated by previous studies, ${ }^{25,26,28}$ QUS could allow assessing the influence of underlying diseases on the bone tissue.

\section{Conclusion}

The present study demonstrated that QUS was able to show bone microarchitecture alterations in patients with BRONJ and suggested that these analyses may be an important tool for early detection of bone degeneration associated with BRONJ. 


\section{References}

1. Black DM, Cummings SR, Karpf DB, Cauley JA, Thompson $\mathrm{DE}$, Nevitt MC, et al. Randomised trial of effect of alendronate on risk of fracture in women with existing vertebral fractures. Fracture Intervention Trial Research Group. Lancet. 1996 Dec;348(9041):1535-41.

2. Berenson JR, Hillner BE, Kyle RA, Anderson K, Lipton A, Yee GC, et al. American Society of Clinical Oncology clinical practice guidelines: the role of bisphosphonates in multiple myeloma. J Clin Oncol. 2002 Sep;20(17):3719-36.

3. Ruggiero SL, Dodson TB, Fantasia J, Goodday R, Aghaloo T, Mehrotra B, et al. American Association of Oral and Maxillofacial Surgeons position paper on medication-related osteonecrosis of the jaw--2014 update. J Oral Maxillofac Surg. 2014 Oct;72(10):1938-56. doi: 10.1016/j.joms.2014.04.031.

4. Ruggiero SL, Mehrotra B, Rosenberg TJ, Engroff SL. Osteonecrosis of the jaws associated with the use of bisphosphonates: a review of 63 cases. J Oral Maxillofac Surg. 2004 May;62(5):527-34.

5. Marx RE, Sawatari Y, Fortin M, Broumand V. Bisphosphonate-induced exposed bone (osteonecrosis/osteopetrosis) of the jaws: risk factors, recognition, prevention, and treatment. J Oral Maxillofac Surg. 2005 Nov;63(11):1567-75. doi: 10.1016/j.joms.2005.07.010.

6. Advisory Task Force on Bisphosphonate-Related Ostenonecrosis of the Jaws AAoO, Maxillofacial S. American Association of Oral and Maxillofacial Surgeons position paper on bisphosphonate-related osteonecrosis of the jaws. J Oral Maxillofac Surg.2007 Mar;65(3):369-76. doi: 10.1016/j.joms.2006.11.003.

7. Khan AA, Morrison A, Hanley DA, Felsenberg D, McCauley LK, O'Ryan F, et al. Diagnosis and management of osteonecrosis of the jaw: a systematic review and international consensus. J Bone Miner Res. 2015 Jan;30(1):3-23. doi: 10.1002/jbmr.2405.

8. Woo SB, Hande K, Richardson PG. Osteonecrosis of the jaw and bisphosphonates. N Engl J Med. 2005 Jul 7;353(1):99-102; discussion 99-102.

9. Woo SB, Hellstein JW, Kalmar JR. Narrative [corrected] review: bisphosphonates and osteonecrosis of the jaws. Ann Intern Med. 2006 May 16; 144(10):753-61.

10. McLeod NM, Brennan PA, Ruggiero SL. Bisphosphonate osteonecrosis of the jaw: a historical and contemporary review. Surgeon. 2012 Feb;10(1):36-42. doi: 10.1016/j.surge.2011.09.002.

11. Giolo De Carvalho F, de Souza Santos R, Iannetta R, Marques Miguel Suen V, Marliere Navarro A, Nonino Borges CB, et al. Analysis of bone microarchitecture related to anthropometry in climateric women. Nutr Hosp. 2012 Mar-Apr;27(2):612-6. doi: 10.1590/S0212-16112012000200039.

12. Baroncelli GI. Quantitative ultrasound methods to assess bone mineral status in children: technical characteristics, performance, and clinical application. Pediatr Res. 2008 Mar;63(3):220-8. doi: 10.1203/PDR.0b013e318163a286.
13. Yasar F, Akgunlu F. The differences in panoramic mandibular indices and fractal dimension between patients with and without spinal osteoporosis. Dentomaxillofac Radiol. 2006 Jan;35(1):1-9. doi: 10.1259/dmfr/97652136.

14. Taguchi A, Suei Y, Sanada M, Ohtsuka M, Nakamoto T, Sumida $\mathrm{H}$, et al. Validation of dental panoramic radiography measures for identifying postmenopausal women with spinal osteoporosis. AJR Am J Roentgenol. 2004 Dec;183(6):1755-60. doi: 10.2214/ajr.183.6.01831755.

15. Khan AA, Sandor GK, Dore E, Morrison AD, Alsahli M, Amin $\mathrm{F}$, et al. Canadian consensus practice guidelines for bisphosphonate associated osteonecrosis of the jaw. J Rheumatol. 2008 Jul;35(7):1391-7.

16. FedeleS, Porter SR, D'Aiuto F, Aljohani S, Vescovi P, Manfredi $\mathrm{M}$, et al. Nonexposed variant of bisphosphonate-associated osteonecrosis of the jaw: a case series. Am J Med. 2010 Nov;123(11):1060-4. doi: 10.1016/j.amjmed.2010.04.033.

17. Chiandussi S, Biasotto M, Dore F, Cavalli F, Cova MA, Di Lenarda R. Clinical and diagnostic imaging of bisphosphonate-associated osteonecrosis of the jaws. Dentomaxillofac Radiol. 2006 Jul;35(4):236-43. doi: $10.1259 / \mathrm{dmfr} / 27458726$.

18. Ruggiero S, Gralow J, Marx RE, Hoff AO, Schubert MM, Huryn JM, et al. Practical guidelines for the prevention, diagnosis, and treatment of osteonecrosis of the jaw in patients with cancer. J Oncol Pract. 2006 Jan;2(1):7-14.

19. Ruggiero SL, Dodson TB, Assael LA, Landesberg R, Marx RE, Mehrotra B, et al. American Association of Oral and Maxillofacial Surgeons position paper on bisphosphonate-related osteonecrosis of the jaws--2009 update. J Oral Maxillofac Surg. 2009 May;67(5 Suppl):2-12. doi: 10.1016/j.joms.2009.01.009.

20. Colella G, Campisi G, Fusco V. American Association of Oral and Maxillofacial Surgeons position paper: Bisphosphonate-Related Osteonecrosis of the Jaws-2009 update: the need to refine the BRONJ definition. J Oral Maxillofac Surg. 2009 Dec;67(12):2698-9. doi: 10.1016/j.joms.2009.07.097.

21. Bedogni A, Blandamura S, Lokmic Z, Palumbo C, Ragazzo M, Ferrari F, et al. Bisphosphonate-associated jawbone osteonecrosis: a correlation between imaging techniques and histopathology. Oral Surg Oral Med Oral Pathol Oral Radiol Endod. 2008 Mar;105(3):358-64. doi: 10.1016/j.tripleo.2007.08.040.

22. Bisdas S, Chambron Pinho N, Smolarz A, Sader R, Vogl TJ, Mack MG. Biphosphonate-induced osteonecrosis of the jaws: CT and MRI spectrum of findings in 32 patients. Clin Radiol. 2008 Jan;63(1):71-7. doi: 10.1016/j.crad.2007.04.023.

23. O'Ryan FS, Khoury S, Liao W, Han MM, Hui RL, Baer D, et al. Intravenous bisphosphonate-related osteonecrosis of the jaw: bone scintigraphy as an early indicator. J Oral Maxillofac Surg. 2009 Jul;67(7):1363-72. doi: 10.1016/j.joms.2009.03.005. 
24. Thumbigere-Math V, Tu L, Huckabay S, Dudek AZ, Lunos S, Basi DL, et al. A retrospective study evaluating frequency and risk factors of osteonecrosis of the jaw in 576 cancer patients receiving intravenous bisphosphonates. Am J Clin Oncol. 2012 Aug;35(4):386-92. doi: 10.1097/COC.0b013e3182155fcb.

25. Boonyapakorn T, Schirmer I, Reichart PA, Sturm I, Massenkeil G. Bisphosphonate-induced osteonecrosis of the jaws: prospective study of 80 patients with multiple myeloma and other malignancies. Oral Oncol. 2008 Sep;44(9):857-69. doi: 10.1016/j.oraloncology.2007.11.012.

26. Pluskiewicz W, Halaba Z, Chelmecka L, Drozdzowska B, Sonta-Jakimczyk D, Karasek D. Skeletal status in survivors of acute lymphoblastic leukemia assessed by quantitative ultrasound at the hand phalanges: a longitudinal study. Ultrasound Med Biol. 2004 Jul;30(7):893-8. doi: 10.1016/j.ultrasmedbio.2004.04.012.

27. Baroncelli GI. Quantitative bone analysis in children: current methods and recommendations. J Pediatr. 2006 May;148(5):704; author reply 704. doi: 10.1016/j.jpeds.2006.01.012.

28. Mussa A, Bertorello N, Porta F, Galletto C, Nicolosi MG, Manicone $\mathrm{R}$, et al. Prospective bone ultrasound patterns during childhood acute lymphoblastic leukemia treatment. Bone. 2010 Apr;46(4):1016-20. doi: 10.1016/j.bone.2009.12.019.

29. Hans D, Schott AM, Meunier PJ. Ultrasonic assessment of bone: a review. Eur J Med. 1993 Mar;2(3):157-63.

30. Passos JS, Gomes Filho IS, Sarmento VA, Sampaio DS, Goncalves FP, Coelho JM, et al. Women with low bone mineral density and dental panoramic radiography. Menopause. 2012 Jun;19(6):704-9. doi: 10.1097/gme.0b013e318240f938. 